\title{
In vivo antioxidant activity of hydroalcoholic extract of Taraxacum officinale roots in rats
}

In the traditional system of medicine, there are a number of plants which are used in the treatment of liver disorders. Their extract, fractions, and active constituents exhibit marked hepatoprotective action, which has been related to their antioxidant properties. ${ }^{[1]}$ Traditionally, Taraxacum officinale, WEBER, family Compositae, commonly known as "Dandelion" has been used as a remedy for jaundice, other disorders of the liver and gall bladder, and to counteract water retention.

Free radicals are reactive molecules involved in many physiological processes and human diseases, such as cancer, aging, arthritis, Parkinson's syndrome, ischemia and liver injury. The elevation of free radical levels seen during the liver damage is owing to enhanced production of free radicals and decreased scavenging potential of the cells. A variety of intrinsic antioxidants (reduced glutathione, superoxide dismutase (SOD), catalase and peroxidase) are present in the organism, which protect them from oxidative stress, thereby forming the first line of defence. ${ }^{[2]}$ The present study was undertaken to evaluate antioxidant activity of $70 \%$ hydroalcoholic extract of roots of T. officinale (TO) in rats.

The plant TO was collected from the Gandhi Krishi Vigyan Kendra (GKVK), Bangalore, in the month of December 2002 and was authenticated by Dr. Yoganarsimhan, Scientist, Regional Research Centre [Ay], Bangalore. The dry powder of roots of TO was extracted with $70 \%$ alcohol in a soxhlet apparatus for $24 \mathrm{~h}$ at approximately $60^{\circ} \mathrm{C}$. The extract was then concentrated by distilling the solvent below $60^{\circ} \mathrm{C}$ and dried in a dessicator. A suspension was prepared by using equal volumes of the extract and gum acacia for administration to rats using oral gague. The chemicals used for investigation of antioxidant activity were $\mathrm{CCl}_{4}$ (Quality Fine Chemicals Ltd. India), Liv-52 (Himalaya, India), hydroxylamine hydrochloride (Sigma, India), nitro-blue tetrazoleum (NBT) (Sigma, India), hydrogen peroxide, EDTA, and Ellman's reagent (Sigma, India). All other chemicals obtained from local sources were of analytical grade.

Albino rats of Wistar strain, weighing 100-150 g, maintained on normal diet (Amrut Laboratory Animal Feeds, Bangalore) and water ad libitum, were divided into five groups of six animals each. Before starting the experiment, permission from the Institutional Animal Ethics Committee was obtained.

Group-I animals served as normal control, treated with distilled water. Group-II animals served as hepatotoxic control, treated with $\mathrm{CCl}_{4}$ in a single dose of $1.5 \mathrm{ml} / \mathrm{kg}$, i.p., to produce acute hepatotoxicity. Group III served as a standard group, and was administered Liv-52 in a dose of $56 \mathrm{mg} / \mathrm{kg}$, p.o. Group-IV and $-\mathrm{V}$ animals were treated with daily doses of
50 and $100 \mathrm{mg} / \mathrm{kg}$, p.o., respectively, of TO extract for 7 days. The animals of Groups III-V were given single dose of $\mathrm{CCl}_{4}$, $1.5 \mathrm{ml} / \mathrm{kg}$, i.p., $6 \mathrm{~h}$ after the last treatment. On day 8 the rats were sacrificed by carotid bleeding and liver was rapidly excised, rinsed in ice-cold saline, and a $10 \% \mathrm{w} / \mathrm{v}$ homogenate was prepared using $0.15 \mathrm{M} \mathrm{KCI}$, centrifuged at $800 \mathrm{~g}$ for 10 min at $4^{\circ} \mathrm{C}$. The supernatant obtained was used for the estimation of catalase, peroxidase, and lipid peroxidation. Further, the homogenate was centrifuged at $1000 \mathrm{~g}$ for 20 min at $4^{\circ} \mathrm{C}$ and the supernatant was used for estimation of SOD and glutathione

Estimation of SOD was done by autoxidation of hydroxylamine at $\mathrm{pH} 10.2$, which was accompanied by reduction of NBT, and the nitrite produced in the presence of EDTA was detected colorimetrically. ${ }^{[3]}$ One enzymatic unit of SOD is the amount in the form of proteins present in $100 \mu \mathrm{l}$ of $10 \%$ liver homogenate required to inhibit the reduction of $24 \mathrm{mM}$ NBT by $50 \%$ and is expressed as units per milligram of protein.

Catalase activity was estimated by determining the decomposition of $\mathrm{H}_{2} \mathrm{O}_{2}$ at $240 \mathrm{~nm}$ in an assay mixture containing phosphate buffer. ${ }^{[4]}$ One international unit of catalase utilized is that amount that catalyzes the decomposition of $1 \mathrm{mM} \mathrm{H} \mathrm{H}_{2} / \mathrm{min} / \mathrm{mg}$ of protein at $37^{\circ} \mathrm{C}$. Catalase activity was calculated using the millimolar extinction coefficient of 0.07 and expressed in terms of micromole per minute per milligram of protein.

Glutathione was estimated using Ellman's reagent $(5,5 \mathbf{c}-$ dithiobis-(2-nitrobenzoic acid) [DTNB]). The sulphydryl groups present in glutathione forms a colored complex with DTNB, which was measured colorimetrically at $412 \mathrm{~nm} . .^{[5]}$ The amount of glutathione was determined using its molar extinction coefficient of $13600 / \mathrm{m} / \mathrm{cm}$ and expressed in terms of $\mu \mathrm{mol} / \mathrm{mg}$ of protein.

Peroxidase estimation is based on periodide formation. Periodide can be spectrophotometrically determined at 353 $\mathrm{nm}$, and this is directly proportional to the peroxidase concentration in the reaction mixture containing approximate amounts of $\mathrm{H}_{2} \mathrm{O}_{2}$ and enzyme. ${ }^{[6]}$ One unit of peroxidase activity is defined as the change in absorbance per minute and expressed in terms of units per milligram of protein.

Malondialdehyde (MDA), a secondary product of lipid peroxidation, reacts with thiobarbituric acid at $\mathrm{pH}$ 3.5. The red pigment produced was extracted in $n$-butanol-pyridine mixture, and estimated by measuring the absorbance at $532 \mathrm{~nm} \cdot .^{[7]}$

Results were subjected to one-way ANOVA. $\mathrm{P}<0.05$ was considered significant. The post hoc analysis was carried out by Dunnet's multiple comparison test. 
Table 1

Effect of TO extract on antioxidant enzymes

\begin{tabular}{|c|c|c|c|c|c|}
\hline Treatment & $\begin{array}{c}\text { SOD } \\
\text { (U/mg of protein) }\end{array}$ & $\begin{array}{c}\text { Catalase } \\
(\mu M / \mathrm{min} / \mathrm{mg} \text { of protein })\end{array}$ & $\begin{array}{c}\text { Glutathione } \\
(\mu \mathrm{M} / \mathrm{mg} \text { of protein) }\end{array}$ & $\begin{array}{c}\text { Peroxidase } \\
\text { (U/mg of protein) }\end{array}$ & $\begin{array}{c}\text { Lipid peroxidation } \\
\text { ( } n M M D A / g \text { of protein) }\end{array}$ \\
\hline Control & $13.35 \pm 0.58$ & $181.05 \pm 29.8$ & $18.619 \pm 0.094$ & $267 \pm 11.70$ & $6.25 \pm 0.92$ \\
\hline $\mathrm{CCl}_{4}$ control & $7.49 \pm 0.21^{a}$ & $76.60 \pm 0.47^{a}$ & $8.196 \pm 0.767^{a}$ & $113.5 \pm 8.40^{a}$ & $24.14 \pm 3.12^{a}$ \\
\hline Standard Liv-52 & $12.42 \pm 0.43^{b}$ & $144.57 \pm 4.78^{b}$ & $12.168 \pm 0.072^{c}$ & $197.2 \pm 10.2^{c}$ & $14.80 \pm 1.71^{c}$ \\
\hline $50 \mathrm{mg} / \mathrm{kg} \mathrm{TO}$ & $9.89 \pm 0.96^{c}$ & $101.02 \pm 3.39^{c}$ & $8.981 \pm 0.064$ & $152 \pm 4.06^{c}$ & $20.11 \pm 2.46$ \\
\hline TO $100 \mathrm{mg} / \mathrm{kg}$ & $11.04 \pm 0.33^{b}$ & $125.88 \pm 6.66^{b}$ & $11.906 \pm 0.184^{b}$ & $184 \pm 5.02^{b}$ & $15.89 \pm 2.02^{c}$ \\
\hline One-way & 91.135 & 43.248 & 333.37 & 237.45 & 27.222 \\
\hline ANOVA & $<0.001$ & $<0.05$ & $<0.01$ & $<0.001$ & $<0.05$ \\
\hline
\end{tabular}

Values are mean \pm SEM. $n=6$ in each group; $\mathrm{df}=4,25 ;{ }^{a} P<0.001$ compared to control, ${ }^{b} P<0.001,{ }^{c} P<0.01$, compared to hepatotoxic control.

As shown in Table 1, $\mathrm{CCl}_{4}$ treatment decreased SOD, catalase, glutathione, and peroxidase and increased lipid peroxidation. Pretreatment with $100 \mathrm{mg} / \mathrm{kg}$ (p.o.) of TO extract improved the SOD, catalase, glutathione, and peroxidase levels significantly and reduced lipid peroxidation. SOD is a ubiquitous cellular enzyme that dismutates superoxide radical to $\mathrm{H}_{2} \mathrm{O}_{2}$ and oxygen and is one of the chief cellular defence mechanisms. The $\mathrm{H}_{2} \mathrm{O}_{2}$ formed by SOD and other processes is scavenged by catalase that catalyzes the dismutation of $\mathrm{H}_{2} \mathrm{O}_{2}$ into water and molecular oxygen. Thus, the antioxidant enzyme catalase is responsible for detoxification of $\mathrm{H}_{2} \mathrm{O}_{2}$ Glutathione is a tripeptide of glycine, glutamic acid, and cysteine. Glutathione is an important naturally occurring antioxidant as it prevents the hydrogen of sulfhydryl group to be abstracted instead of methylene hydrogen of unsaturated lipids. Therefore, levels of glutathione are of critical importance in tissue injury caused by toxic substances. The antioxidant enzymes and glutathione form the first line of defence against free radical-induced damage, offer protection against free radicals, and thereby maintain low levels of lipid peroxide. ${ }^{[3]}$ Peroxidase is an enzyme that catalyzes the reduction of hydroperoxides, including hydrogen peroxides, and functions to protect the cell from peroxidative damage. As the TO extract, in the dose of 100 $\mathrm{mg} / \mathrm{kg}$, p.o., has improved the SOD, catalase, glutathione, and peroxidase levels significantly, which were comparable with
Liv 52. ${ }^{[2]}$ We conclude that the hydroalcoholic extract from the root of TO possesses antioxidant activity, confirming the traditional use of the plant in treatment of liver disorders.

Meera Sumanth, A.C. Rana*

Al Ameen college of Pharmacy, Hosur Road, Opp. Lalbagh Main Gate, Bangalore 560 027, India. *Department of Pharmacological Sciences, Dr. H. S. Gour University, Sagar 470 003, Madhya Pradesh, India.

E-mail: meera2004in@indiatimes.com

\section{References}

1. Handa SS. Manual, TCDC International Workshop cum Training on Herbal Drugs. 1997.

2. Sandhir R, Gill KD. Hepatoprotective effects of Liv-52 on ethanol induced liver damage in rats. Indian J Expt Biol 1999;37:762-6.

3. Kono Y. Generation of superoxide radical during autoxidation of hydroxylamine and an assay for superoxide dismutase. Arch Biochem Biophys 1978;186:189-95.

4. Luck H. In: Methods of enzymatic analysis. Bergmeyer HU, editor. Vol. 3. New York: Academic Press; 1971.

5. Buetler E, Duron O, Kelly BM. Improved method for determination of blood glutathione. J Lab Clin Med 1963;61:882-8.

6. Alexander NM. A spectrophotometric assay for iodide oxidation by thyroid peroxidase. Anal Biochem 1962;4:341-5.

7. Ohkawa H, Ohishi N, Yagi K. Assay for lipid peroxides. In: Animal tissue by thiobarbituric acid reaction. Anal Biochem 1979;95:351-8. 